LA W RENCE LIVERMORE NATIONAL LABORATORY

Clearwater and Wineskin Sub-CAU Flow and Transport Models

S. F. Carle

July 30, 2012 
This document was prepared as an account of work sponsored by an agency of the United States government. Neither the United States government nor Lawrence Livermore National Security, LLC, nor any of their employees makes any warranty, expressed or implied, or assumes any legal liability or responsibility for the accuracy, completeness, or usefulness of any information, apparatus, product, or process disclosed, or represents that its use would not infringe privately owned rights. Reference herein to any specific commercial product, process, or service by trade name, trademark, manufacturer, or otherwise does not necessarily constitute or imply its endorsement, recommendation, or favoring by the United States government or Lawrence Livermore National Security, LLC. The views and opinions of authors expressed herein do not necessarily state or reflect those of the United States government or Lawrence Livermore National Security, LLC, and shall not be used for advertising or product endorsement purposes.

This work performed under the auspices of the U.S. Department of Energy by Lawrence Livermore National Laboratory under Contract DE-AC52-07NA27344. 


\section{Clearwater and Wineskin Sub-CAU Flow and Transport Models}

Background. The Clearwater (U12q) test of 1963 and the Wineskin (U12r) test of 1969 each have a $200 \mathrm{kt}$ maximum announced yield (USDOE, 2000). Together, these two vertical shaft tests constitute about $25 \%$ of the total maximum yield on Rainier Mesa (Bowen et al., 2001). Their western location requires assessment of radionuclide flux to the Timber Mountain regional volcanic aquifer (Fenelon et al., 2008) or Redrock Valley Aquifer or "RVA" (NSTec, 2007). The Clearwater and Wineskin sub-CAU modeling objective is to generate realistic distributions of groundwater flow and radionuclide transport flux (realizations) using ranges of flow and transport properties bounded by data, flow calibration, and radionuclide concentration measurements. Key uncertainty variables include: (1) fraction of infiltration reaching the RVA, (2) fracture permeability and porosity in the TCU, (3) altered zone permeability and porosity enhancement, (4) hydraulic head in the RVA adjacent to the tests, (5) the radionuclide source term, and (6) transport mobility properties including Kd, tortuosity, and penetration depth of radionuclides into the matrix. Between 225 and 2160 realizations of radionuclide transport were generated for each of the 11 radionuclide sources (see Table 1), with the number of realizations depending on number of cases needed to address uncertainty variables - 5 flow cases, 3 transport mobility cases, 3 source term magnitudes, 3 to 5 source term spatial distributions, 1 to 4 melt glass partition fractions, and 1 to 3 melt glass dissolution fractions. Realizations exceeding $0.1 \mathrm{MCL}$ to the RVA at any time between 0 and 1000 years post-test time were forwarded to the CAU model.

(a) Clearwater

Table 1. Number of realizations (N) and number and fraction of realizations exceeding 0.1 and 1.0 MCL concentrations to the RVA for (a) Clearwater and (b) Wineskin. Fractions exceeding MCL cutoffs are higher for Clearwater than Wineskin because ofcloser proximity to the RVA.

\begin{tabular}{|c|r|r|r|r|r|}
\hline $\begin{array}{c}\text { Radio- } \\
\text { nuclide }\end{array}$ & N & \multicolumn{2}{|c|}{$>\mathbf{0 . 1}$ MCL } & \multicolumn{2}{|c|}{$>\mathbf{1 . 0}$ MCL } \\
\hline & N & \multicolumn{1}{|c|}{$\%$} & \multicolumn{1}{|c|}{ N } & \multicolumn{1}{c|}{$\%$} \\
\hline H-3 & 225 & 225 & 100 & 225 & 100 \\
\hline C-14 & 225 & 225 & 100 & 215 & 96 \\
\hline Cl-36 & 450 & 450 & 100 & 300 & 67 \\
\hline I-129 & 450 & 450 & 100 & 450 & 100 \\
\hline TC-99 & 450 & 450 & 100 & 102 & 23 \\
\hline U-238 & 450 & 196 & 44 & 0 & 0 \\
\hline Sr-90 & 450 & 438 & 97 & 414 & 92 \\
\hline Pu-238 & 2160 & 1059 & 49 & 646 & 30 \\
\hline Pu-239 & 2160 & 1390 & 64 & 1020 & 47 \\
\hline Pu-240 & 2160 & 1123 & 52 & 743 & 34 \\
\hline Am-241 & 1440 & 367 & 25 & 129 & 9 \\
\hline
\end{tabular}

(b) Wineskin

\begin{tabular}{|c|c|c|c|c|c|}
\hline \multirow{2}{*}{$\begin{array}{l}\text { Radio- } \\
\text { nuclide }\end{array}$} & \multirow[t]{2}{*}{$\mathbf{N}$} & \multicolumn{2}{|c|}{$>0.1 \mathrm{MCL}$} & \multicolumn{2}{|c|}{$>1.0 \mathrm{MCL}$} \\
\hline & & $\mathrm{N}$ & $\%$ & $\mathrm{~N}$ & $\%$ \\
\hline $\mathrm{H}-3$ & 225 & 225 & 100 & 225 & 100 \\
\hline C-14 & 225 & 225 & 100 & 180 & 80 \\
\hline $\mathrm{Cl}-36$ & 450 & 386 & 86 & 300 & 67 \\
\hline $\mid-129$ & 450 & 450 & 100 & 405 & 90 \\
\hline Tc-99 & 450 & 412 & 92 & 40 & 10 \\
\hline$U-238$ & 450 & 87 & 19 & 0 & 0 \\
\hline $\mathrm{Sr}-90$ & 450 & 46 & 10 & 18 & 4 \\
\hline Pu-238 & 2160 & 106 & 5 & 48 & 2 \\
\hline Pu-239 & 2160 & 539 & 25 & 281 & 13 \\
\hline Pu-240 & 2160 & 377 & 17 & 138 & 6 \\
\hline Am-241 & 1440 & 0 & 0 & 0 & 0 \\
\hline
\end{tabular}

For both tests, a model cavity radius ( $\mathrm{Rc}$ ) of $72 \mathrm{~m}$ is derived from maximum announced yield (Pawloski, 1999; USDOE, 2000). Each sub-CAU model is developed specific to the hydrostratigraphic framework model (HFM) and the hydrogeologic setting of Rainier Mesa (Fenelon et al. 2008; Carroll, 1990) using updated hydrostratigraphic interpretations of drill hole RME\#1 (Townsend and Townsend, 2004; NSTec, 2009; Drellack, 2010) to provide more likely constraints on RVA location adjacent to the Clearwater and Wineskin tests. Compared to the base HFM model (NSTec, 2007), for Clearwater, the RVA top is raised about 1 Rc closer to the working point, and for Wineskin, the RVA is thickened and extended northward to the edge of the granitic MGCU, which is assumed impermeable as in the CAU model.

Flow Model. Figure 1 shows general set up of the flow model. Pre-test flow conditions are steady-state, and post-test flow conditions are transient due to test-induced enhancements to porosity and permeability. For recharge, INFIL3 realization \#11 used by the CAU model prescribes a steady-state surface inflow boundary condition in all flow and transport models. Discharge to the RVA is varied as a fraction of INFIL3 inflow (e.g., 60 to $100 \%$ for Clearwater), with the remainder flowing laterally to vitric tuff aquifers. Lacking CAU flow model calibration of RVA head, five flow model cases were developed for each test with a range of RVA head boundary conditions: for Clearwater, 1550, 1575, 1600, 1625, 
and $1650 \mathrm{~m}$, and for Wineskin, 1550, 1587, 1625, 1662, and $1700 \mathrm{~m}$. At Clearwater, a perched water table measurement of $1707 \mathrm{~m}$ from U12q emplacement hole provides a key constraint for calibration of downward flow through the TCU to the RVA. Figure 1 shows simulated fracture and matrix saturation for the Clearwater $1600 \mathrm{~m}$ and Wineskin 1625m RVA head flow cases. Importantly, saturation fields for all flow cases are consistent with saturated matrix below the upper level of pervasive zeolitization (Carroll, 1990; Townsend et al., 2007; Townsend, 2008) and the elevation below which fractures are fully saturated as constrained by 19 perched water level measurements on Rainier Mesa (Thordarson, 1965; Fenelon et al., 2008) including recent flooded N- and T-tunnel water levels (Stoller-Navarro, 2007a).

Matrix permeability dominates flow in vitric tuff aquifers, and fracture permeability dominates flow in welded tuff aquifers (Stoller-Navarro, 2006 and 2008; Townsend, 2008). Direct observations of flow in Rainier Mesa tunnels and shafts indicate that fractures dominate flow in the TCU (Thordarson, 1965; Townsend et al., 2007; Townsend, 2008). The flow models focus on assessing fracture flow uncertainty in the TCU as a key variable for assessing radionuclide transport uncertainty between test locations and the RVA. TCU fracture permeability and porosity are different in each of five flow cases, while matrix flow properties in the volcanic section are constrained by the 58 most accurate of 65 data from Kwicklis et al. (2009). Corrections were made to these matrix property data for porosity, permeability, and van Genuchten parameters to address revised RME\#1 (hydro) stratigraphic interpretation, zeolite and smectite mineral hydration, Ksat overestimation by flexible wall tubes, and standard error in alpha parameter. Flow calibration using the $1707 \mathrm{~m}$ perched water level together with INFIL3 infiltration rates constrains TCU fracture hydraulic conductivity to between 0.4 and $2.5 \mathrm{E}-9 \mathrm{~m} / \mathrm{s}$, one to two orders of magnitude higher than estimated matrix permeability. Model TCU fracture porosity range between 0.5 and 5.7E-4 based on TCU fracture aperature and spacing data (Prothro, 2008). The same matrix and fracture flow properties applied to Clearwater flow cases are extended to five Wineskin flow cases, which exhibit greater uncertainty in two respects: (1) a larger range of RVA head and (2) variable perched water levels that bracket the working point elevation.

In test-altered zones at Rainier Mesa, permeability is enhanced in fractures to $3 \mathrm{Rc}$ and in the matrix to 2 Rc (US Congress, 1989). Although no direct measurements of test-altered permeability and porosity are available from Rainier Mesa, fracture permeability testing from the Hardhat test in granite (Boardman, 1966; Boardman and Skrove, 1966) provides insight. The bottom row of Figure 1 shows model fracture and matrix permeability including test altered zones for the Clearwater $1600 \mathrm{~m}$ RVA head flow case. The five flow cases span up to two orders of magnitude of uncertainty in enhanced fracture permeability within 3Rc, with increasing permeability inward toward the working point. The flow models indicate flow transients caused by test-enhanced permeability and porosity last for decades to centuries and increase TCU fracture flow velocity between radionuclide source locations and the RVA. Similar to the Nash test source term model constrained by water level and tritium data in Yucca Flat (Carle et al., 2008), the transport model includes test-induced transient flow effects that will enhance radionuclide transport to the regional aquifer compared to a steady-state flow assumption.

Transport Model. For each of the eleven radionuclides of the Hydrologic Source Term (HST) model, H-3, C-14, Cl-36, I-129, Tc-99, U-238, Sr-90, Pu-238, Pu-239, Pu-240, and Am-241, the transport model explicitly varies the properties of source magnitude, source spatial distribution, sorption, and matrix diffusivity including ranges of uncertainty. Each radionuclide source term is initially partitioned into void space or fractures of five zones: melt glass, cavity, 1-1.5Rc, 1.5-3Rc, and chimney zones. Radionuclides with melt glass partitioning have additional uncertainty ranges for glass fraction and glass dissolution. The transport model realizations cover the entire range of uncertainty for the source term model and sorption coefficients specific to each radionuclide and rock type. Uncertainty in matrix diffusivity is addressed by using radionuclide-specific diffusion coefficients and a tortuosity-porosity relationship 
(Stoller-Navarro, 2007b) with a factor of \pm 2.0 uncertainty. Colloidal transport for Pu and Am isotopes is addressed by applying an additional 0.1 multiplier to the tortuosity factor to represent a $90 \%$ and $10 \%$ portioning of $\mathrm{Pu}$ and $\mathrm{Am}$ isotopes into colloidal and aqueous phases, respectively, within fractures. Transport parameter uncertainty is addressed by using three transport mobility settings (LM, MM, HM) for radionuclide-specific parameters including Kd, tortuosity, and average penetration depth into the matrix (Neretnieks, 1980), which is assumed limited by physical barriers and sorption. For rubble source zones - the cavity, melt glass, and chimney - the model considers that strongly sorbing radionuclides distribute preferentially into smaller particles having larger surface area to volume ratio, while nonsorbing radionuclides distribute more completely throughout rubble of various sizes (Rabb, 1970).

The transport model results are compared to radionuclide concentration data of three kinds (1) source zones of other NNSS tests with similar hydrogeologic settings (Hot Well data) , (2) T tunnel discharge after Mighty Oak test "radioactive materials leaked ...into vessel III" (U.S. Congress, 1989), and (3) impounded T tunnel water extracted from behind the gas-seal plug (GSP). The T tunnel data show consistency with the Hot Well data suggesting that $T$ tunnel data are representative of source zone concentrations at Rainier Mesa. Figure 2 shows H-3, I-129, Sr-90, and Pu-239 transport modeling results for Clearwater. The first column shows concentrations derived from source term initialization into fractures and voids, while the second column shows fracture and void concentration at a later time representative of transport behavior. The third column shows maximum concentration at the top of the RVA, where a $0.1 \mathrm{MCL}$ cutoff determines whether or not a transport realization is forwarded to the CAU model. The fourth column shows cumulative fraction of the source discharging to the RVA, with 1.0 representing the entire radionuclide source term. Realizations are colored by mobility setting: red $=$ $\mathrm{HM}$, green $=\mathrm{MM}$, blue $=\mathrm{LM}$. Uncertainty in source term magnitude is not included in the realizations, but can be post-processed for an uncertainty range ( \pm 1.3 to 3.0 ) shown in the third column.

Because of the close proximity of the RVA below Clearwater, comparison of model concentrations at the top of the RVA to Hot Well and T tunnel data is pertinent, particularly for tracers. Maximum model concentration to the RVA is reasonably expected to be similar to a source zone concentration (for example, see $\mathrm{H}-3$ and $\mathrm{I}-129$ model concentrations in Figure 2 at 10 years). The numerous $\mathrm{T}$ tunnel and NNSS H-3 data are important for model calibration to aqueous tracer concentrations. Clearwater model realizations show consistency with and bracket NNSS and T tunnel $\mathrm{H}-3$ data and the higher concentration I-129 data, confirming the model has a realistic representation of uncertainty. Consistency between model and measured Sr-90 concentrations indicates that the model is also effective for highly sorbing radionuclides. For Pu-239, the model produces concentrations similar to observations with consideration of delay in Pu-239 transport to the top of the RVA. Overall, LM and MM cases are most consistent with data, while HM cases are certainly useful for assessment of conservative transport parameter settings. The transport model applied to the Wineskin test results in more delayed and reduced radionuclide flux to the RVA (Figure 3) compared to Clearwater; for sorbing radionuclides, transport cases exceed $0.1 \mathrm{MCL}$ for only a small fraction of only HM transport mobility settings.

Transport modeling results for other long half-life tracers $\mathrm{C}-14, \mathrm{Cl}-36$, and Tc-99 are similar to I-129 with differences mainly related to initial source magnitude. U-238 and Am-241 transport results are below the $\mathrm{MCL}$, consistent with observations, except for a small percentage of unlikely high mobility cases. For all plutonium species, a large model uncertainty derives from the source term uncertainty of 0 to $5 \%$ fraction not initially sequestered into melt glass. For example, the model can produce Pu-239 concentrations over $100 \mathrm{MCL}$, whereas Pu-239 has been rarely observed over the $\mathrm{MCL}$. In general the Clearwater and Wineskin sub-CAU models produce water and radionuclide fluxes consistent with established hydrogeologic conceptual models, recharge estimates, fracture flow observations, water level data, rock property data, source term uncertainty, and radionuclide concentration data. 


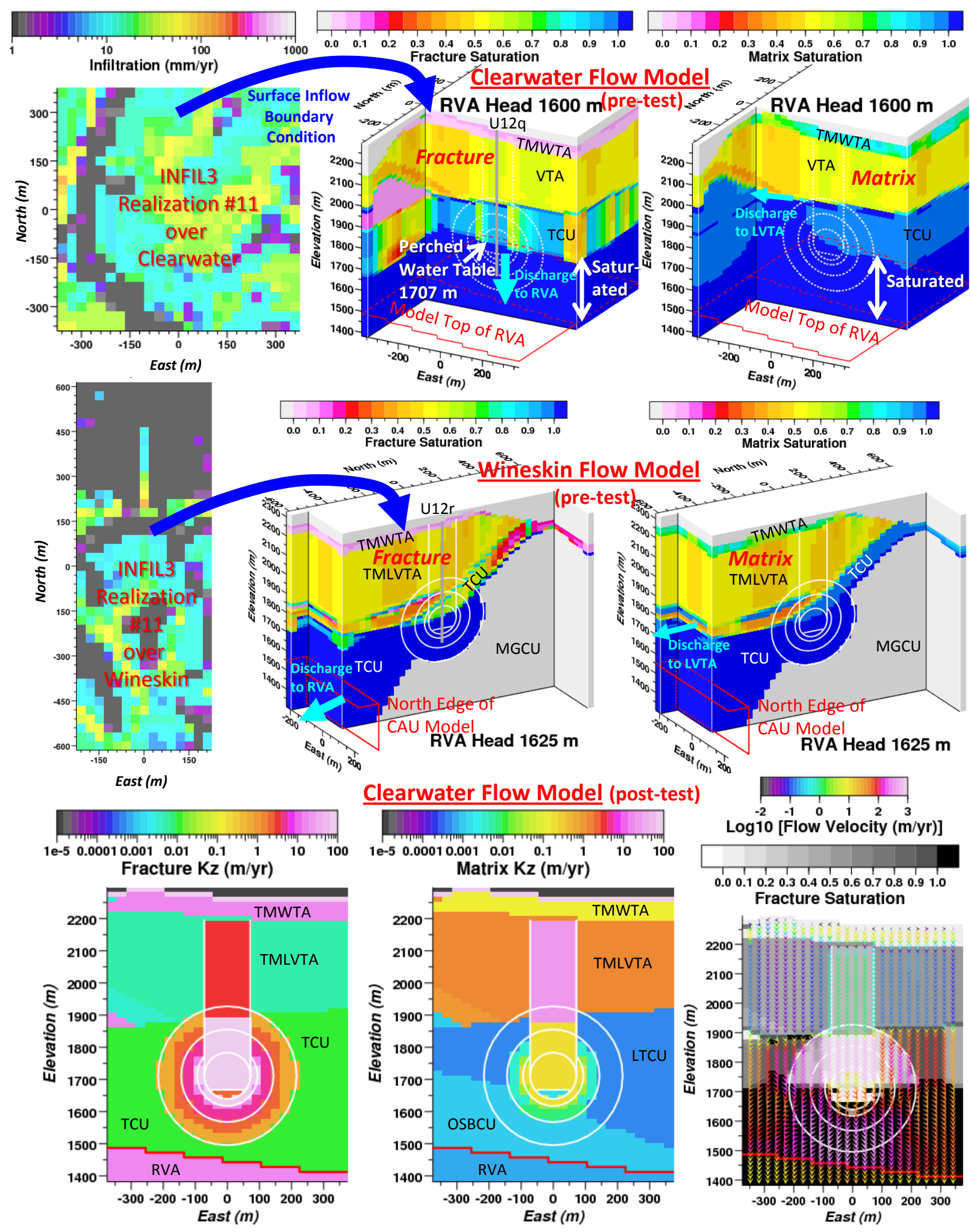

Figure 1. Overview of Clearwater (row 1) and Wineskin (row 2) flow models, with details on permeability and transient fracture flow velocity and saturation for Clearwater at 1 year (row 3). Model cavity radius (Rc) of $72 \mathrm{~m}$ is derived from maximum announced yield (Pawloski, 1999; USDOE, 2000). 


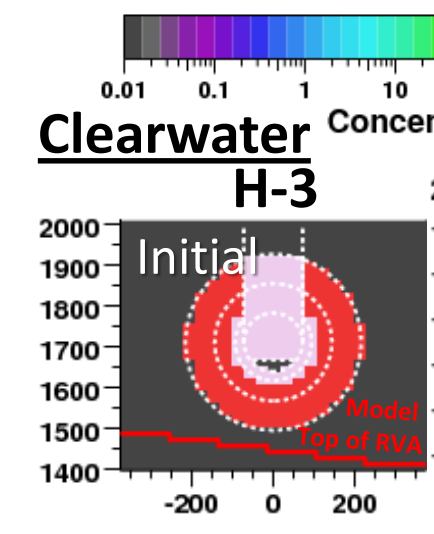

Elevation
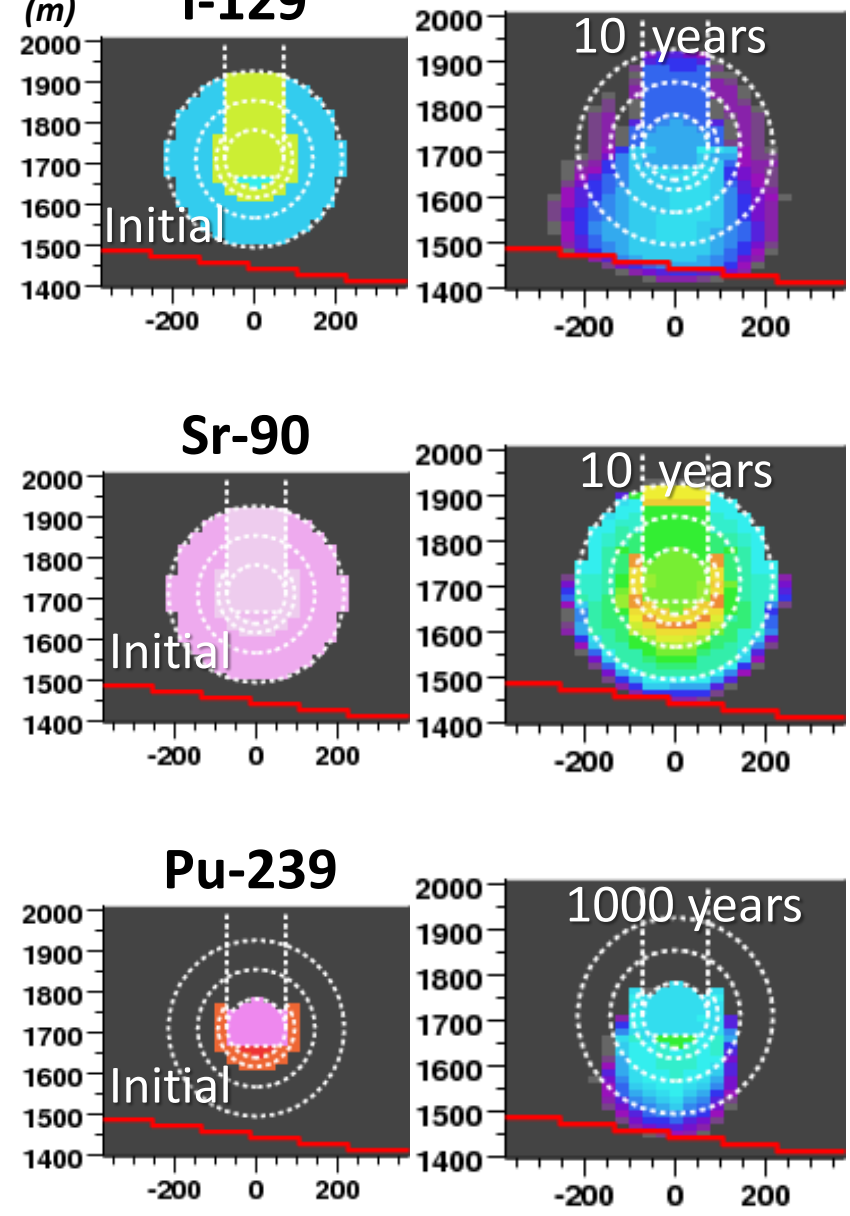

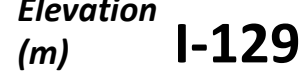

Maximum Concentration at Top of RVA (MCL)
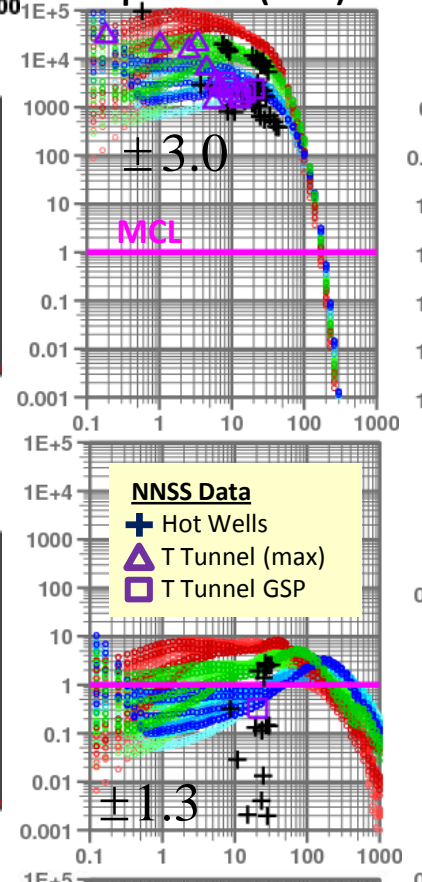

Figure 2. Clearwater transport model results for $\mathrm{H}-3, \mathrm{I}-129, \mathrm{Sr}-90$, and $\mathrm{Pu}-239$ radionuclide sources. The first column shows an example of the initial concentration distribution in fractures and voids, and the second column shows fracture and void concentrations at a time after the test. The third and fourth columns show maximum concentration (MCL units) and cumulative fraction of the radionuclide source to the RVA, respectively, for all model realizations within the bounds of the plots as function of time since test. Maximum concentrations to RVA are compared to NNSS Hot Well and T tunnel data. Model cavity radius ( $\mathrm{Rc}$ ) of $72 \mathrm{~m}$ is derived from maximum announced yield (Pawloski, 1999; USDOE, 2000). 

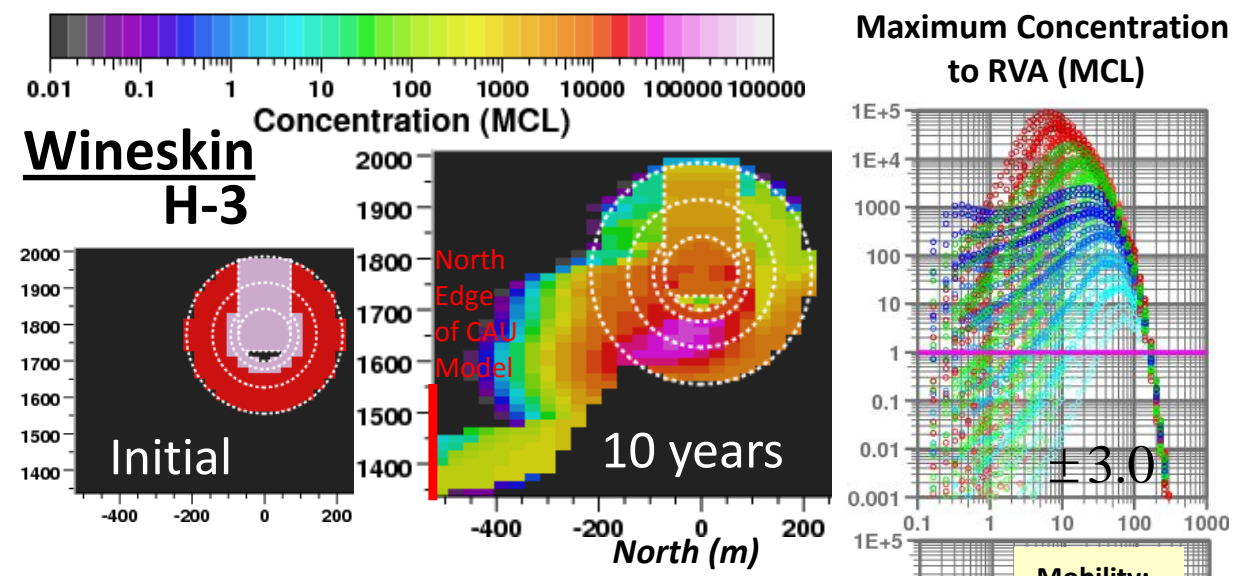

\section{Cumulative Fraction} of Source to RVA
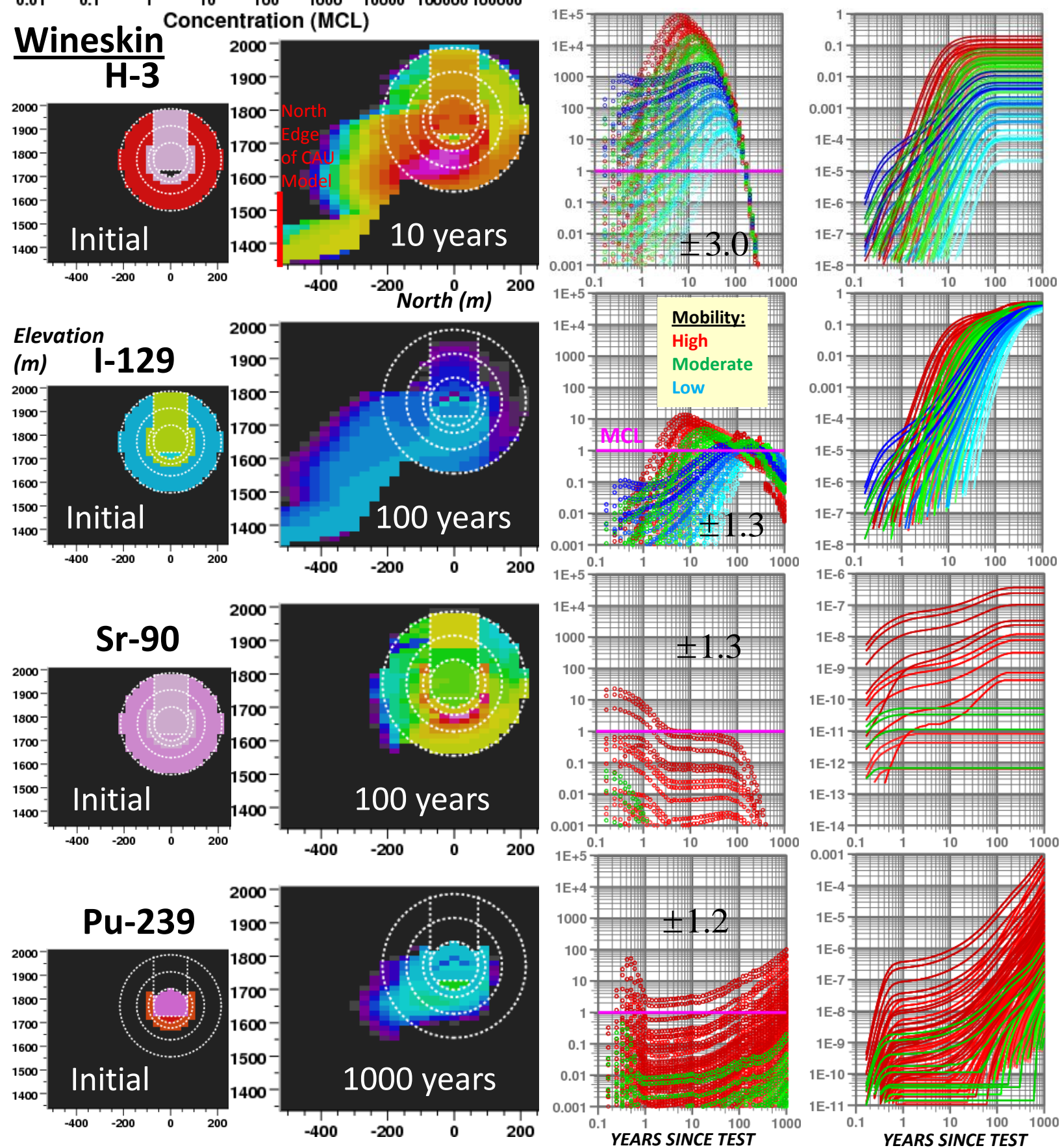

Figure 3. Wineskin transport model results for $\mathrm{H}-3, \mathrm{I}-129, \mathrm{Sr}-90$, and $\mathrm{Pu}-239$ radionuclide sources. The first column shows an example of the initial concentration distribution in fractures and voids, and the second column shows fracture and void concentrations at a time after the test. The third and fourth columns show maximum concentration (MCL units) and cumulative fraction of the radionuclide source to the RVA, respectively, for all model realizations within the bounds of the plots as function of time since test. Model cavity radius (Rc) of $72 \mathrm{~m}$ is derived from maximum announced yield (Pawloski, 1999; USDOE, 2000). 


\section{References}

Boardman, C. R. (1966), Some Characteristics of the Hardhat Chimney and Surrounding Wall Rock, Lawrence Radiation Laboratory, URCL-50177.

Boardman, C. R., and Skrove, J. (1966) Distribution in fracture permeability of a granitic rock mass following a contained nuclear explosion, Lawrence Radiation Laboratory, UCRL-14292 Rev. II

Bowen, S. M., Finnegan, D. L., Thompson, J. L., Miller, C. M., Baca, P. L., Olivas, L. F., Geoffrion, C. G., Smith, D. K., Goishi, W., Esser, B. K., Meadows, J. W., Namboodiri, N., and Wild, J. F. (2001), Nevada National Security Site Radionuclide Inventory, 1951-1992, LA-13859-MS, Los Alamos National Laboratory, Los Alamos, NM.

Carle, S. F., Zavarin, M., Sun, Y., and Pawloski, G. A., (2008), Evaluation of Hydrologic Source Term Processes for Underground Nuclear Tests in Yucca Flat, Nevada National Security Site: Carbonate Tests: LLNL-TR-403485, Lawrence Livermore National Laboratory

Carroll, R. D., (1990), Electrical Logging and Electrical Properties of Rocks in Rainier Mesa Area, Nevada National Security Site, Nevada, U.S. Geological Survey Open-File Report 90-31.

Drellack, S, (2010), written communication, document "NW_RM_EV_changes_DOC_rev1.pdf"

Fenelon, J. M., Laczniak, R. J., and Halford, K. J. (2008), Predevelopment Water-Level Contours for Aquifers in the Rainier Mesa and Shoshone Mountain Area of the Nevada National Security Site, Nye County, Nevada, Scientific Investigations Report 2008-5044, U.S. Geological Survey

Kwicklis, E., WoldeGabriel, G., and Sulley, M. (2009), Analysis of core-scale hydrologic and mineralogic data from boreholes UE12t \#1 and RME \#1 at Rainier Mesa, Nevada National Security Site, LAUR-XXXX, Los Alamos National Laboratory.

Neretnieks, I. (1980), Diffusion in the Rock Matrix: An Important Factor in Radionuclide Retardation?, Journal of Geophysical Research, v. 85, n. B8, p. 4379-4397.

NSTec (2007), A Hydrostratigraphic Model and Alternatives for the Groundwater Flow and Contaminant Transport Model of Corrective Action Unit 99: Rainier Mesa-Shoshone Mountain, Nye County, Nevada, National Security Technologies, LLC , DOE/NV/25946-146.

NSTec (2009), Geology and Hydrogeology of Rainier Mesa Exploratory \#1, Unpublished data by National Security Technologies, LLC, dated April 16, 2009.

Pawloski, G. A. (1999), Development of Phenomenological Models of Underground Nuclear Tests on Pahute Mesa, Nevada National Security Site - BENHAM and TYBO, UCRL-ID-136003, Lawrence Livermore National Laboratory, Livermore, CA.

Prothro, L B., (2008), Analysis of Fractures in Cores from the Tuff Confining Unit beneath Yucca Flat, Nevada National Security Site, National Security Technologies DOE/NV/25946-351.

Stoller-Navarro (2006), Phase I Hydrologic Data for the Groundwater Flow and Contaminant Transport Model of Correction Action Unit 97: Yucca Flat/Climax Mine, Nevada National Security Site, Nye County, Nevada. S-N/99205-077

Stoller-Navarro (2007a), U12n and U-12t Tunnels Preliminary Data Report Groundwater Sampling Stoller-Navarro (2007b), Phase I Contaminant Transport Parameters for the Groundwater Flow and Contaminant Transport Model of Corrective Action Unit 97: Yucca Flat/Climax Mine, Nevada National Security Site, Nye County, Nevada. S-N/99205-096Stoller-Navarro (2008a), Phase I Hydrologic Data for the Groundwater flow and Contaminant Transport Model of Corrective Action Unit 99: Rainier Mesa/Shoshone Mountain, Nevada National Security Site, Nye County, Nevada

Rabb, D. D., (1970), Particle-Size Distribution Study: Piledriver Event, Lawrence Radiation Laboratory, CONF-700101(vol. 2) 
Stoller-Navarro (2008) Phase I Hydrologic Data for the Groundwater Flow and Contaminant Transport Model of Correction Action Unit 99: Rainier Mountain/Shoshone Mountain, Nevada Test Site, Nye County, Nevada. S-N/99205--103

Thordarson, W. (1965) Perched Ground Water in Zeolitized-Bedded Tuff, Rainier Mesa and Vicinity, Nevada National Security Site, Nevada, TEI-862, U.S. Geological Survey, 98p

Townsend, D. R., and Townsend, M. J., (2004) Underground Test Area Geology Task to Construct Database of Drill-Hole and Stratigraphic Information for the Rainier Mesa Area

Townsend, D. R., Townsend, M., and Ristvet, B. L. (2007), A Geotechnical Perspective on Post-Test Data for Underground Nuclear Tests Conducted in Rainier Mesa, DOE/MV/25946-269.

Townsend, D. R. (2008), Documentation Report for Rainier Mesa Test Information Compiled for the UGTA Project, Wastren Adavantage Incorporated.

U.S. Congress (1989), The Containment of Underground Nuclear Explosions, Office of Technology Assessment OTA-ISC-414 (Washington D.C.: US Government Printing Office, October 1989) 85p.

USDOE (2000), United States Nuclear Tests: July 1945 through September 1992, DOE/NV-209 (Rev. 15), Department of Energy, Las Vegas, NV. 